\title{
The applications of GNSS systems in logistics
}

\author{
Kamil Maciuk \\ Katedra Geodezji Zintegrowanej i Kartografi, Wydziat Geodezji Górniczej i Inżynierii Środowiska, \\ AGH Akademia Górniczo-Hutnicza, e-mail: maciuk@agh.edu.pl
}

\begin{abstract}
The development of navigation satellite systems allows them to be used in many areas of trade, services and industry. This development is strongly visible in industries related to logistics and transportation where car navigation is becoming a standard for all kinds of vehicles. In this paper the author discusses navigation satellite systems, the principle of their operation and presents analysis of possible applications in businesses related to logistics and transport.
\end{abstract}

Keywords: transport, logistics, satellite systems, GPS, GNSS.

\section{Introduction}

The concept of GNSS (Global Navigation Satellite System) currently includes four global systems: GPS (Global Positioning System, managed by USA), GLONASS (ГЛОНАCС, Глобальная навигационная спутниковая система - Russian satellite navigation system, Russia), Galileo (European Union) and BeiDou (China). There are also regional navigation satellite systems: BeiDou-1 (5 geostationary satellites), NAVIC (Navigation with Indian Constellation, India) and QZSS (Quasi-Zenith Satellite System, Japan). GNSS systems use satellites circulating around the Earth to determine a user's position. A GNSS receiver allows us to determine the components of latitude, longitude and height with an accuracy reaching up to a single millimetre. The calculation is based on the knowledge of the transmission time of signal retransmitted by satellites.

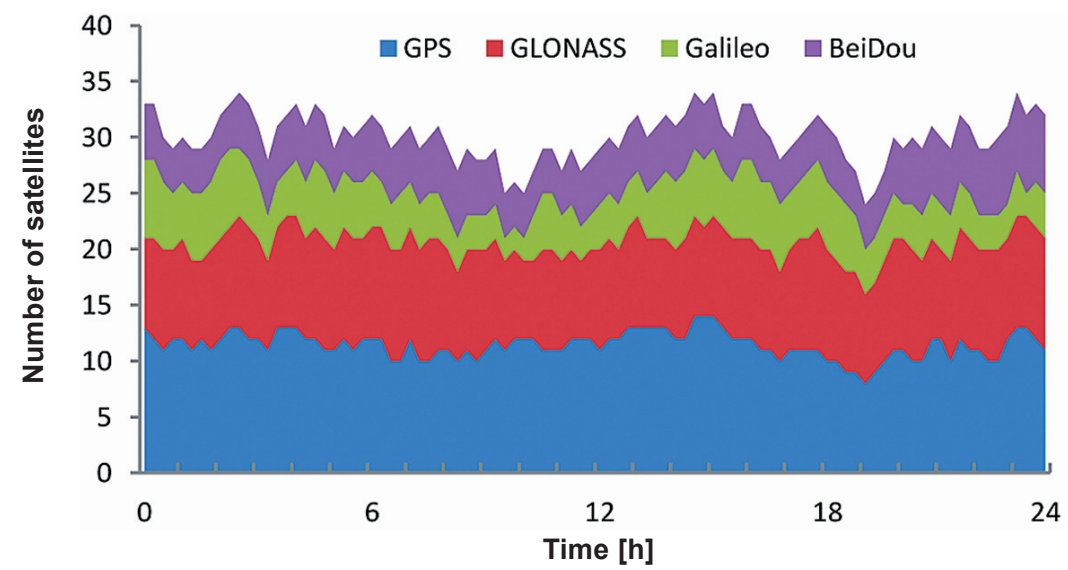

Fig. 1. Number of visible satellites (Source: Author's elaboration) 
Among the currently available fully operational GNSS systems (nominal number of satellites in the orbit) there are only two: GPS and GLONASS. BeiDou and Galileo should also be fully operational in the upcoming few years. Currently there are $79^{1}$ satellites (GPS 31, GLONASS - 23, Galileo - 12, BeiDou - 13) which ensure simultaneous visibility of at least $25-30$ of them at any latitude. Fig. 1 shows the example of a daily graph of visibility of GNSS satellites over Krakow (500 'N, $19^{\circ} 57^{\prime}$ E).

Growing number of available satellites allows the elimination of long and uncomfortable observation sessions, which had to be planned in advance at the beginning of satellite measurement era in 1980s and 1990s. It also gives the opportunity to use satellite navigation systems in the areas where it was previously impossible due to very large terrain obstacles e.g., in mountainous or urbanized areas.

\section{The operation principle}

The principle of GNSS systems operation is based on the knowledge of signal propagation time along the distance 'satellite-receiver' and satellites' parameters. Each satellite transmits code the replica of which is generated simultaneously by the receiver. From the time shift of the satellite signal registered in the receiver, the approximate distance is calculated due to the knowledge of signal speed (speed of light - $299792458 \mathrm{~m} / \mathrm{s}$ ). In addition, each satellite transmits parameters of its position and speed. Finally, the receiver calculates its own position on the basis of distances and satellites' location using a spatial intersection (Fig. 2).

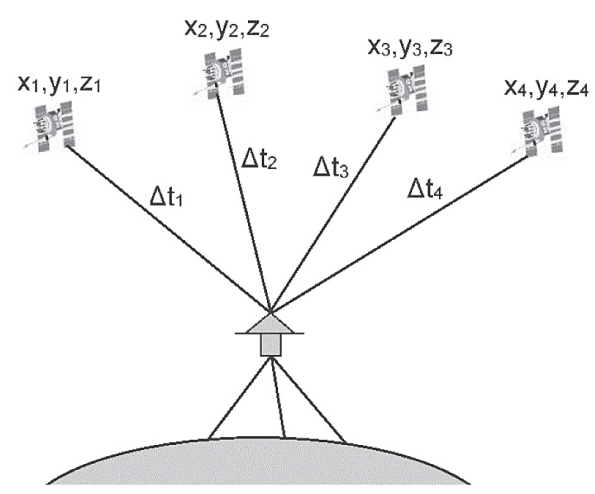

Fig. 2. The principle of GNSS operation (Source: Author's elaboration)

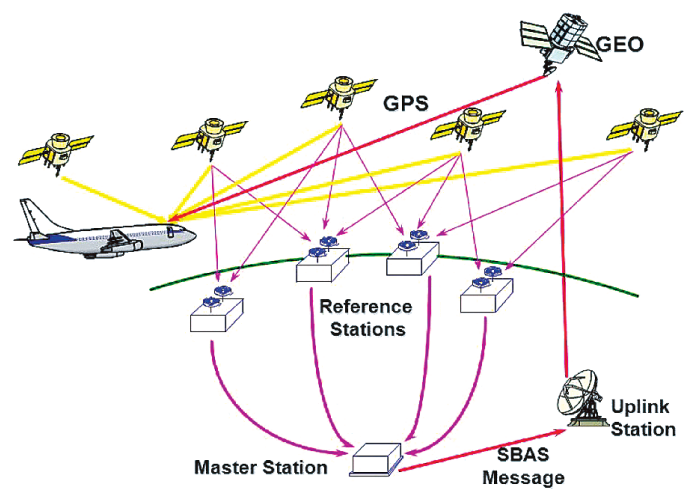

Fig. 3. The principles of SBAS operation (Source: http://slideplayer.com/slide/752289, access: 2016-08-14)

To determine the position of a GNSS receiver a simultaneous visibility of at least four satellites is required (four unknowns: three position components and receiver clock error). In theory, the accuracy of determination increases proportionally to the number of visible satellites and their geometry. Studies show that the use of receivers using signals from more than one satellite navigation system allows to conduct measurements where it was impossible so far, e.g., in mountainous or urbanized areas $[1,2]$.

1 http://gpsworld.com/the-almanac/, access: 2016-07-10 
Depending on the required accuracy, various types and methods of satellite measurements are used. Due to the type of used signals, one can distinguish code and phase measurements. In turn, due to the number of receivers used to determine the absolute (single receiver) and differential position (two or more receivers), different solution types may be defined. The most accurate are differential phase measurements allowing us to obtain results with millimetre accuracy. They are most often used in surveying or civil engineering. In most areas where the accuracy of GNSS solutions at a level of a few meters is sufficient, a single receiver enabling code solutions is used. Such precision is provided by the simplest, manual satellite receivers currently used in smartphones or car navigation.

GNSS systems are complemented by supporting satellite systems called SBAS (Satellite Based Augmentation System - satellite support systems). SBAS monitoring stations (Reference Stations, Fig. 3) register signals transmitted by satellites, based on the known coordinates of the satellites their position error is determined. Then, the information is transmitted to the data center (Master Station) where the signal corrections and credentials of the GNSS and SBAS systems are calculated. These data via transmitting stations (Uplink Station) are sent to the satellites of the SBAS system [3]. The example of SBAS systems is the European EGNOS (European Geostationary Navigation Overlay Service) or the American WAAS (Wide Area Augmentation System).

SBAS systems are mainly used in aviation, shipping or rescue services and their main task is to increase the reliability and continuity of conducting satellite measurements and to reduce the time needed to determine the position. An undoubted disadvantage is the availability of geostationary satellite signals from SBAS system. Geostationary satellites maintain fixed position above the selected point on the Earth's Equator and thus, their horizontal height accuracies decrease along with geographical latitudes of observation sites. Therefore, in selected areas limited by natural or artificial terrain obstacles, SBAS measurements are not applicable.

\section{GNSS usage}

Satellite navigation systems are used in a number of areas of human life, but the most common application is broadly understood navigation, i.e. supporting air, rail or car transport, including tourist traffic. In addition, GNSS systems are used by various types of specialist industries. Receivers with the highest accuracy reaching single millimetres are used in survey and construction. Receivers of lower accuracy are used by other engineering fields, such as geology (mapping and recording geological objects), cartography (mapping) or archaeology (records of archaeological sites). Navigation satellite systems are also used in determining parameters of reference systems [4], movements of the Earth's crust [5] or determining the impact of flood [6]. In addition, they are used in radio communication to create coverage maps, tourism, agriculture for planning and optimization of crops or fishery to track migration of fisheries. Of course, the list of applications is very extensive, and the above mentioned are only small examples.

\section{The use of GNSS in logistics companies}

The most popular and most widely used by various transport companies is GNSS-based car-navigation. It has almost completely replaced analogue maps used so far. Constant advances in the development of electronic devices and software brought a significant drop in 
cost of their purchase and thus, they have become more available also for small businesses or private users. Car-navigation is mainly used by freight forwarder/shipping companies, transport companies, taxi corporations as well as by individual road users. In large transport companies, GNSS systems are used very widely as a tool supporting the base-driver communication, allowing the optimal control of the fleet [7]. The main advantages of using navigation in transport companies are: reduction of the number of accidents, reduction in fuel consumption or increasing prestige of the company [8]. The knowledge of the traffic situation allows us to bypass traffic jams and sites of accidents, allows us to reduce fuel costs and save time, and the bi-directional communication with the base allows us to track the deployment of transport fleet and route optimization or counteract mismanagement and theft of fuel. As shown by the research, the use of GPS by transport companies allows them to reduce the limit of kilometres travelled on average by about $370 \mathrm{~km}$ a week by a single vehicle [9].

Comprehensive solutions using, among others, GNSS systems are called ITS (Intelligent Transport Systems). ITS support the organization of efficient and optimal supply and safe transport as the basis for the work of modern distribution networks of both local and global reach [10]. The principle of ITS operation is based on two-way communication based on information on the location and condition of vehicles. The forwarder can keep drivers informed about the route, weather conditions, traffic situation, etc. This allows better control of the forwarder's work over the course of transport processes, and in the case of vehicle theft or alarm, it enables remote control of devices installed in it, e.g. by cutting off the fuel supply. The GNSS receiver installed in the vehicle allows to control, among others, vehicle position, fuel combustion, travelled distance, turnover or work of other equipment [11]. A practical example of intelligent vehicle control system is Globtrak [12]. It has been designed to control and monitor all types of machines and vehicles or other devices equipped with a fuel system (e.g. refrigeration units). Globtrak allows collecting information about vehicle and analysing data like fuel consumption, use of the vehicle, operation of devices and others. The motion location system itself can be enlarged by several other functions and sensors (Fig. 4). Depending on the application, the vehicle can be equipped, for example, with a door and luggage compartment opening sensor, as well as temperature and air conditioning sensors.

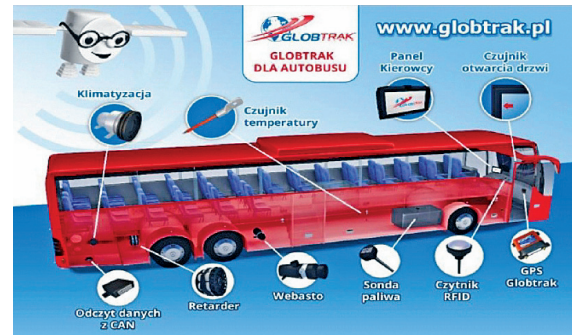

Fig. 4. An example of Globtrack sensor distribution in a bus [12]

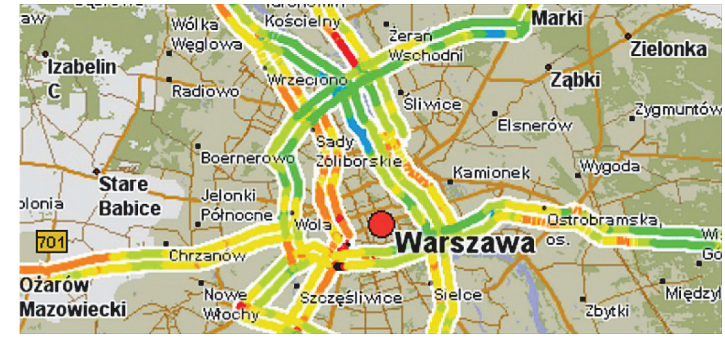

Fig. 5. Map of Warsaw traffic jams [22]

The innovative solution of Globtrak is the CAN system which allows us to analyse the behaviour of a particular driver based on vehicle speed, engine speed, frequency of using brake or gas pedal, etc. It allows the elimination of economically negative habits of drivers. Another solution is a probe placed in the fuel tank that allows the control of fuel consumption by the vehicle and the control of the filler cap opening, enabling the cessation of the fuel trade by dishonest drivers. 
In the case of public transport, the use of GNSS allows informing passengers about current bus/tram/train status and possible delays. An example of this type of application may be messages at railway stations or information at bus stops (arrival time). In case of modern taxi companies, the charging system depends on the route being travelled by GNSS display. In this mode the route fee is known in advance regardless the traffic jams. The choice of vehicle by the forwarding agent is selected based on the auto-navigation indication that optimizes the entire process of the time of arrival; in addition, the passenger is accurately informed about the waiting time for a taxi.

In courier and forwarding companies GNSS systems are used to determine the current location all vehicles and hence the status of shipments and their approximate delivery time. For example, in Speedmail company, a national postal operator, the delivery process is monitored based on the GPS system. It is based on the use of Targeo digital maps with an advanced courier tracking system based on GPS route outlines. It allows the verification of the effectiveness of parcel delivery. To ensure the highest quality of services in terms of timeliness, the control of courier routes allows the company to optimize areas of delivery of parcels [18], and the recipient to check where the shipment is currently located via the web application [13].

The satellite system is also used in the field of transport protection and control. For example, approximately 50,000 passenger cars, 1,400 trucks and about 6,600 vans are stolen annually on the Polish territory [14]. Even the best car alarms, immobilizers or other security devices do not guarantee their complete safety. Therefore especially owners of expensive cars or transport companies try to minimize the risk of losing the vehicle to a minimum using vehicle tracking satellite systems. An example of this type of vehicle is the use of GNSS technology in connection with GSM mobile technology. The stolen vehicle's position is transmitted on the current basis via the GSM network to the base/owner. Due to the global area of operation of GNSS systems, the only limitation of this type of security is the range of the mobile telephone network. However it should be noted that the vehicle monitoring system using satellite navigation systems is not perfect for two reasons. First of all its operation is fully dependent on the range of mobile telephony and secondly; there are devices jamming satellite signals (so-called jammers) available on market. They are widely known and used by car thieves. Currently there are companies which provide services called vehicle tracking and control, as well as other functions, such as settlement of travel times and drivers' working time. Moreover, it is possible to install additional sensors such as fuel flow control or axle load.

Online services allowing us to check the current traffic situation in real time are becoming more and more popular. Google Traffic or Targeo Traffic are ones of the most popular in Poland. Both allow users

to calculate the route based on the most up-to-date map and on the basis of GPS data sent live by smartphones and tablets to users of the system using navigation (Fig. 5).

Applications supporting road users not only in terms of navigation, but also information about the traffic are becoming common. They are used mainly in smartphones and tablets, and the most popular applications of this type used in the Polish territory are Yanosik, iCoyote or AutoRadar. Yanosik is a native program by the Poznan company Netpis advertised as a free auto-navigation and anti-radar [19]. The principle of operation of this type of application is based on the reporting, confirmation and control of existing phenomena by road users (Fig. 6). The main function of Yanosik application in standard auto maps is warning about - among others - speed cameras, speed control or unmarked police patrols, but also have the function of avoiding traffic jams and road congestion in real time. The above functions of the Yanosik application, apart from reducing the costs and time of the vehicle, also allow the improvement of road safety. 


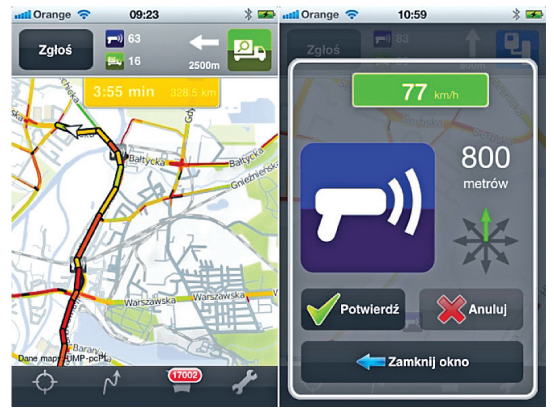

Fig. 6. Sample screens of the Yanosik application [23]

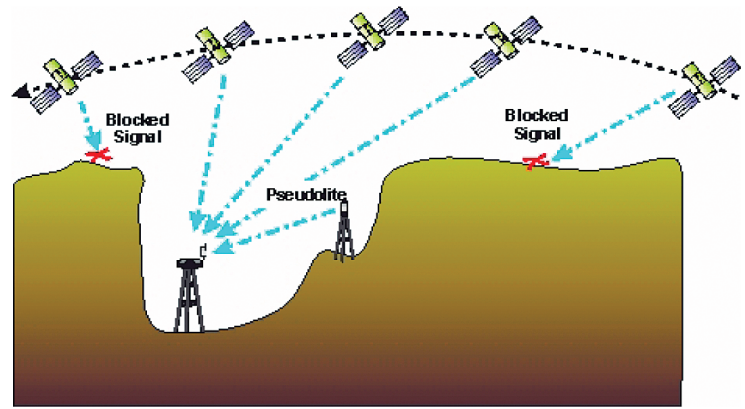

Fig. 7. Principles of pseudolite operation [24]

The principles of driving economy (so called eco-driving) are becoming more and more popular among individual road users as well as owners of transport companies. Drivers who apply eco-driving principles increase road safety, and the amount of fuel saved can be as high as $8 \%$, which allows one month's ride for free on an annual scale [20]. The use of eco-driving rules in large companies or transport corporations using the sensor system in cars enables, among others, reporting on the uneconomical use of vehicles, exceeding the set speed norms and engine revs or too rapid acceleration/braking of the vehicle. The so-called fleet manager can real-time analyse the parameters of the vehicle, its location, driving style and safety, reporting directly to the driver and headquarters, it also gives the opportunity to take appropriate steps in the event of traffic incidents. Eco-driving aims to analyse and - ultimately improve the driving style of individual drivers in the company. In addition, it enables tracking of non-standard fuel consumption set individually for each vehicle, allowing counteraction in case of fuel theft [21].

Standard navigation systems provide the ability to determine the position with insufficient accuracy for some applications. Therefore local DGPS (Differential GPS) systems are created that can also use SBAS systems used, for example, to drive fire brigade vehicles on the airport [15] or ships port dock [16] in conditions of limited visibility. However, mainly in industry and aviation, they are used in the so-called pseudo-satellites (or pseudolites). Pseudolites are generators and signal transmitters on GNSS frequencies located at points with known coordinates; they can be used as support for GNSS signals or as independent systems (Fig. 7).

The most common pseudolites are used at airports to support the take-off and landing of airplanes. However, in industrial plants or factories they can be used as a tool to control the operation of industrial machines or to track the operation of forklifts [17].

\section{Summary}

The first global satellite navigation system was created for military purposes to guide ballistic systems. Currently the signal of all GNSS systems is justified for civilian users, providing free and almost instantaneous information about the time, location and speed of objects. GNSS technology is used in great number of sectors of the economy, becoming a standard tool supporting work in the logistics of people and goods in services, commerce and industry. Today almost every smartphone, sports watch or car are equipped with a GNSS receiver. In addition activities in some areas are based on such solutions and could not function 
without them. Certainly the progressive miniaturization of receivers and the declining prices will further contribute to the widespread use of GNSS systems.

\section{References}

[1] Maciuk K. The influence of adding GLONASS signals on quality of RTK measurements. Geomatics and Environmental Engineering, 9(1) (2015), DOI: 10.7494/geom.2015.9.1.61.

[2] Won D.H., Lee E., Heo M., Sung S., Lee J., Le, Y.J. GNSS integration with vision-based navigation for low GNSS visibility conditions. GPS Solutions. 18 (2) (2013), DOI: 10.1007/s10291-0130318-8.

[3] Woźniak T. EGNOS - prawdy i mity. Część pierwsza, http://dlapilota.pl/wiadomosci/dlapilota/ egnos-prawdy-i-mity-czesc-pierwsza. Access: 2016-08-14, 2011.

[4] Boucher C., Altamimi Z. ITRS, PZ-90 and WGS 84: current realizations and the related transformation parameters. Journal of Geodesy, 75(11) (2001), DOI: 10.1007/s001900100208.

[5] Maciuk K. An analysis of coordinate changes of the permanent geodetic stations KRAW and KRA1 during the flood in 2010. Geomatics and Environmental Engineering, 6(1) (2012), DOI: 10.7494/geom.2012.6.1.51.

[6] Trofimenko S.V., Bykov V.G. Model of crustal block movement in the South Yakutia geodynamic testing area based on GPS data. Russian Journal of Pacific Geology, 8,(4) (2014), DOI: 10.1134/ S1819714014040071.

[7] Definicja Council of Logistics Management (1992), za Coyle J. J., Bardi E. J., Langrey Jr. J. C.: Zarządzanie Logistyczne. Warszawa: Polskie Wydawnictwo Ekonomiczne, (2002).

[8] Leśniak M., Narolski W. Wykorzystanie systemów GPS w logistyce, Logistyka, nr 4, 2007.

[9] Leemekanond N., Akagi F. Logistics Transportation System based on ITS Technology, 2014 IEEE 6th International Conference on Awareness Science and Technology (iCAST), Paris, Date of conference: 29-31 Oct. 2014. DOI: 10.1109/ICAwST.2014.6981835.

[10] Murphy P.R., Wood D.F. Nowoczesna Logistyka, Wydawnictwo Helion, Gliwice, 2010.

[11] Palonka J. Narzędzia technologii informacyjnej wykorzystywane $w$ logistyce $w$ e-gospodarce, Prace Naukowe/Akademia Ekonomiczna w Katowicach, Tom Systemy wspomagania organizacji SWO 2008: informatyka ekonomiczna jako dziedzina nauki i dydaktyki, 2008.

[12] Grębowiec M. Systemy informacyjne i ich zastosowanie w logistyce produktów żywnościowych, Logistyka, $\mathrm{nr}$ 4, (2012)

[13] Jurecki R., Chaba R. Zarządzanie flota pojazdów z wykorzystaniem systemu Globtrak, Logistyka, nr 6, 2014.

[14] Romanow P. Nowe technologie w branży logistyczno-spedycyjnej, Wyższa Szkoła Logistyki w Poznaniu, Warszawa, 2013.

[15] Nosal P. Wykorzystanie systemu monitoringu pojazdów technika GPS w aspekcie ochrony i kontroli transportu, Mobile Computing, Ochrona i kontrola transportu. Zastosowanie technologii GPS w logistyce. Warszawa, 2003.

[16] Sobstel J.W. Rozwój aplikacji nawigacji satelitarnej i monitoringu w Polsce, Przyszłość technik satelitarnych w Polsce, 2006.

[17] Hall, G.W. USCG Differential GPS Navigation Service, Coast Guard Navigation Center Report, 1996.

[18] Kokkoniemi-Tarkkanen H., Kemppi P. Evaluation of Positioning Techniques in Industrial Environment, Research report, Report identification code: VTT-R-02103-09, 2010.

[19] http://www.speedmail.pl/o_firmie.php (access: 2016-09-14).

[20] http://yanosik.pl/pomoc (access: 2016-09-29).

[21] http://www.k2gps.pl/monitoring-logistyczny/eco-driving (access: 2016-09-14).

[22] http://www.motofakty.pl/artykul/eco-driving-na-czym-polega-chodzi-nie-tylko-o-oszczednoscpaliwa.html (access: 2016-09-29). 
[23] http://www.targeo.pl/ juz dziala traffic live.html (access: 2016-08-14).

[24] http://i.wp.pl/a/f/jpeg/27624/yanosik-darmowa-nawigacja-legalny-antyradar-iphonescreen-660.jpeg (access: 2016-08-14).

[25] http://www.wirelessdictionary.com/Wireless-Dictionary-GPS-Pseudo-Satellite-Pseudolites-Definition.html (access: 2016-09-14).

\section{Acknowledgments}

This paper was prepared within the scope of the AGH University of Science and Technology statutory research no. 11.11.150.444 and grant no. 15.11.150.397. 